ORIGINAL ARTICLE

\title{
Total mercury in wild felids occurring in protected areas in the central Brazilian Amazon
}

\author{
Marcelly Castello Branco LOPES ${ }^{1}$, Gabriel Oliveira de CARVALHO ${ }^{1 *} \mathbb{0}$, Robson Roney BERNARDO², \\ Joana MACEDO 3 , Adan Santos LINO ${ }^{1}$, Emiliano Esterci RAMALHO ${ }^{4}$, Daniele KASPER 5 , \\ Rodrigo Ornellas MEIRE², João Paulo Machado TORRES ${ }^{1}$, Olaf MALM ${ }^{1}$

\begin{abstract}
Universidade Federal do Rio de Janeiro, Centro de Ciências da Saúde, Instituto de Biofísica Carlos Chagas Filho, Laboratório de Radioisótopos Eduardo Penna Franca, Av. Carlos Chagas Filho 373, Ilha do Fundão, 21941-902 Rio de Janeiro, Rio de Janeiro, Brasil

2 Universidade Federal do Rio de Janeiro, Instituto de Biofísica Carlos Chagas Filho - Campus Xerém, Estrada de Xerém 27, 25245-390 Duque de Caxias, Rio de Janeiro, Brasil

3 Universidade do Estado do Rio de Janeiro, Faculdade de Formação de Professores, Departamento de Ciências, Programa de Pós Graduação em Ensino de Ciências, Ambiente e Sociedade, Rua Dr. Francisco Portela 1470, Patronato, 24435-005 São Gonçalo, Rio de Janeiro, Brasil

5 Universidade Federal do Rio de Janeiro, Centro de Ciências da Saúde, Instituto de Biofísica Carlos Chagas Filho, Laboratório de Traçadores Ambientais, Av. Carlos Chagas Filho 373, Ilha do Fundão, 21941-902 Rio de Janeiro, Rio de Janeiro, Brasil
\end{abstract} \\ ${ }^{4}$ Instituto de Desenvolvimento Sustentável Mamirauá. Estrada do Bexiga 2584, Bairro Fonte Boa, Tefé, Amazonas, Brasil \\ * Corresponding author: gabriell.goc@biof.ufrj.br; (D) https://orcid.org/0000-0001-9809-2772
}

\section{ABSTRACT}

This is the first study to investigate mercury $(\mathrm{Hg})$ contamination in felid species in the Brazilian Amazon. We collected 26 fur samples from wild felids of four species (Puma concolor, Panthera onca, Leopardus pardalis and Leopardus wiedii) occurring in the Mamirauá and Amanã sustainable development reserves, in the state of Amazonas. Samples were from museum specimens, except for five $P$. onca samples collected from free-living individuals. Total $\mathrm{Hg}$ concentrations ranged from 0.12 to $48.1 \mu \mathrm{g}$ $\mathrm{g}^{-1}$. Concentrations of $\mathrm{Hg}$ did not differ significantly between museum specimens and live individuals of $P$. onca, but varied significantly among species, with significantly higher concentrations for $P$. onca and $L$. pardalis, which could be related to factors such as diet and habitat.

KEYWORDS: conservation, mammals, bioaccumulation, fur, heavy metals

\section{Mercúrio total em felinos selvagens em áreas protegidas na Amazônia central brasileira}

\section{RESUMO}

Este é o primeiro estudo a investigar a contaminação por mercúrio $(\mathrm{Hg})$ em espécies de felinos na Amazônia brasileira. Foram coletadas 26 amostras de pelo de felinos selvagens de quatro espécies (Puma concolor, Panthera onca, Leopardus pardalis e Leopardus wiedii) ocorrendo nas reservas de desenvolvimento sustentável Mamirauá e Amanã, no estado do Amazonas. As amostras foram coletadas de espécimes de museu, exceto cinco amostras de P. onca obtidas de indivíduos capturados em vida livre. As concentraçóes de $\mathrm{Hg}$ variaram de $0,12 \mathrm{a} 48,1 \mu \mathrm{g} \mathrm{g} \mathrm{g}^{-1}$. Não houve diferença significativa entre a concentração de $\mathrm{Hg}$ no pelo de espécimes de museu e de indivíduos vivos de $P$. onca. Houve variação significativa entre espécies, sendo que $P$. onca e $L$. pardalis tiveram concentraçôes significativamente mais altas, o que pode estar relacionado a fatores como dieta e hábitat.

PALAVRAS-CHAVE: conservação, mamíferos, bioacumulacão, pelo, metais pesados

\section{INTRODUCTION}

Several toxic effects of mercury $(\mathrm{Hg})$, a naturally occurring element, have been described in terrestrial and aquatic species over the last 50 years (e.g., Hoffman 2003; Wren 1986; Borg et al. 1969; Burgess et al. 2005; Burgess and Meyer 2008; Dietz et al. 2006; Krey et al. 2015). In vertebrates, hazardous effects of $\mathrm{Hg}$ have been described on the central nervous system, DNA molecular structure, reproductive, cardiovascular, endocrine and immune systems (Wolfe et al. 1998; Scheuhammer et al. 2007; Rice et al. 2014). Additionally, mercury undergoes a biomagnification process, which considerably raises the toxicological risks for top predators (Evers 2018).

In the Amazon basin, artisanal and small-scale gold mining has been one of the main anthropogenic sources of $\mathrm{Hg}$ in the 
environment (Lacerda and Pfeiffer 1992; Bonotto et al. 2018). Beyond gold mining, many other human-driven activities can influence the $\mathrm{Hg}$ cycle and increase contamination in organisms. For example, erosion resulting from deforestation and forest burning can influence the $\mathrm{Hg}$ input to adjacent aquatic systems (Roulet et al. 1998; Farella et al. 2006). In addition, in some Amazonian sub-basins, $\mathrm{Hg}$ concentrations are naturally high (Silva-Forsberg et al. 1999; Lechler et al. 2000; Kasper et al. 2018).

The majority of studies on $\mathrm{Hg}$ contamination has focused on aquatic mammals, due to the known conducive conditions of mercury methylation in some aquatic systems (Ullrich et al. 2001). The terrestrial biota has been less studied worldwide, though it can also be impacted by $\mathrm{Hg}$ accumulation, mainly through the dietary route (Scheuhammer et al. 2007). Amazon felids can be linked to the aquatic environment and reflect levels of aquatic contamination by predating caimans, fishes, large rodents and turtles (Emmons 1987; Silveira et al. 2010). Yet, to date no data exists on $\mathrm{Hg}$ bioaccumulation in Amazon felids.

The main $\mathrm{Hg}$ source for aquatic biota is food intake, and its magnitude of incorporation is related to the trophic level of the organism (Jernelöv and Lann 1971). The Hg that reaches the digestive tract through food ingestion can be absorbed and transferred to the circulatory system, especially for organic mercury molecules such as methylmercury (Boudou and Ribeyre 1985). This $\mathrm{Hg}$ is transported via blood to all tissues, distributed in internal compartments (Wiener et al. 2003) and, due to its affinity for proteins, accumulated in tissues such as muscles and fur (WHO 1990). Therefore, fur usually has higher concentrations of metals and commonly shows a strong positive correlation with internal tissues (Cumbie 1975; Rashed and Soltan 2005; Brait et al. 2009). Fur samples are broadly used as an indicator of $\mathrm{Hg}$ bioaccumulation in wild species worldwide (Burton et al. 1977; Fonseca et al. 2005; Duffy et al. 2005; Mora et al. 2000). The use of fur samples has the additional advantage of being a non-invasive method for the assessment of $\mathrm{Hg}$ levels in wildlife, especially in species that cannot be collected due to ethical and legal reasons.

Felids face serious threats worldwide, especially due to hunting, road traffic accidents and loss of natural habitats (Macdonald and Loveridge 2010). Hg contamination can be an additional threat for felids, as they are top predators and therefore susceptible to biomagnification. Despite the lack of strong evidence for Amazonian felids, there are several studies showing high natural $\mathrm{Hg}$ concentrations in abiotic and biotic compartments in the Amazon, even for non-impacted regions (Lechler et al. 2000; Kasper 2018). This lack of knowledge for felids is mainly associated to the difficulty in capturing live individuals for sample collection, especially in the Amazon region. Thus, the aim of this study was to investigate the concentration of total mercury $(\mathrm{THg})$ in fur samples from four felid species occurring in two sustainable development reserves in the mid Solimóes River basin, in the central Brazilian Amazon, to provide background $\mathrm{Hg}$ concentrations for felids living in a non-impacted environment.

\section{MATERIAL AND METHODS}

Fur samples were collected from individuals occurring in the Mamirauá and Amanã Sustainable Development Reserves (from here on RDS Mamirauá and RDS Amanã, from the Portuguese Reserva de Desenvolvimento Sustentável). Both reserves are located in the middle Solimôes River region, in the state of Amazonas, Brazil (Figure 1). Together, the two reserves cover more than 3,400,000 ha of primary forest, with low human disturbance and high wildlife richness (Ayres 1995), mainly floodplain habitats (regionally known as várzeas) subject to annual flooding of an extensive network of rivers, lakes and connecting channels (Ramalho et al. 2009). Fur samples from five free-living individuals of Panthera onca (Linnaeus, 1758) were collected in 2010. We also obtained fur samples of 21 wild felid specimens kept in the museum of the Mamirauá Sustainable Development Institute, in Tefé, Amazonas: Panthera onca $(\mathrm{n}=9)$, Puma concolor Linnaeus, $1771(\mathrm{n}=3)$, Leopardus pardalis Linnaeus, $1758(\mathrm{n}=8)$ and Leopardus wiedii Schinz, $1821(\mathrm{n}=1)$ (Supplementary Material, Table S1).

The museum specimens were retrieved from local communities and there are no recorded details of their age or cause of death. It is probable, though, that they were illegally hunted or found dead in the region. The taxidermy process was artisanal through sun drying the skin and, in some cases, with the addition of salt. At the museum, these skins were stored in temperature-controlled cabinets with naphthalene. Free-living individuals of $P$. onca were captured for research projects by the Mamirauá Institute. The animals were sedated with Zoletil and Ketamine and were released after sampling procedures. Fur samples from living individuals and from the museum specimens were cut with aluminum scissors from the dorsal region and stored in polyethylene bags. Capture and handling of the wild individuals of $P$. onca was authorized by IBAMA/SISBIO license no. 11095-3.

The analytical procedures were carried out at the Radioisotope Laboratory Eduardo Penna Franca, at the Institute of Biophysics Carlos Chagas Filho, at the Federal University of Rio de Janeiro (Brazil). All $\mathrm{Hg}$ forms present in the sample were quantified. The exogenous contamination from fur samples was previously removed using deionized water. Samples were then kept in an EDTA $0.01 \%$ bath for two hours, followed by rinses with deionized water. After that, they were oven-dried at $40{ }^{\circ} \mathrm{C}$. Approximately $0.01 \mathrm{~g}$ dry weight, in duplicates, were mineralized with $3 \mathrm{~mL}$ of nitric acid $\left(\mathrm{HNO}_{3} 65 \%\right.$, Tedia, Brazil) in a water bath $\left(60^{\circ} \mathrm{C}\right)$ for 30 minutes. Samples were cooled at room temperature, and the oxidation process was completed by the addition of $5 \mathrm{~mL}$ of $5 \%$ potassium permanganate $\left(\mathrm{KMnO}_{4}\right.$ $5 \%$, Tedia, Brazil). Samples were placed in the water bath $(60$ 


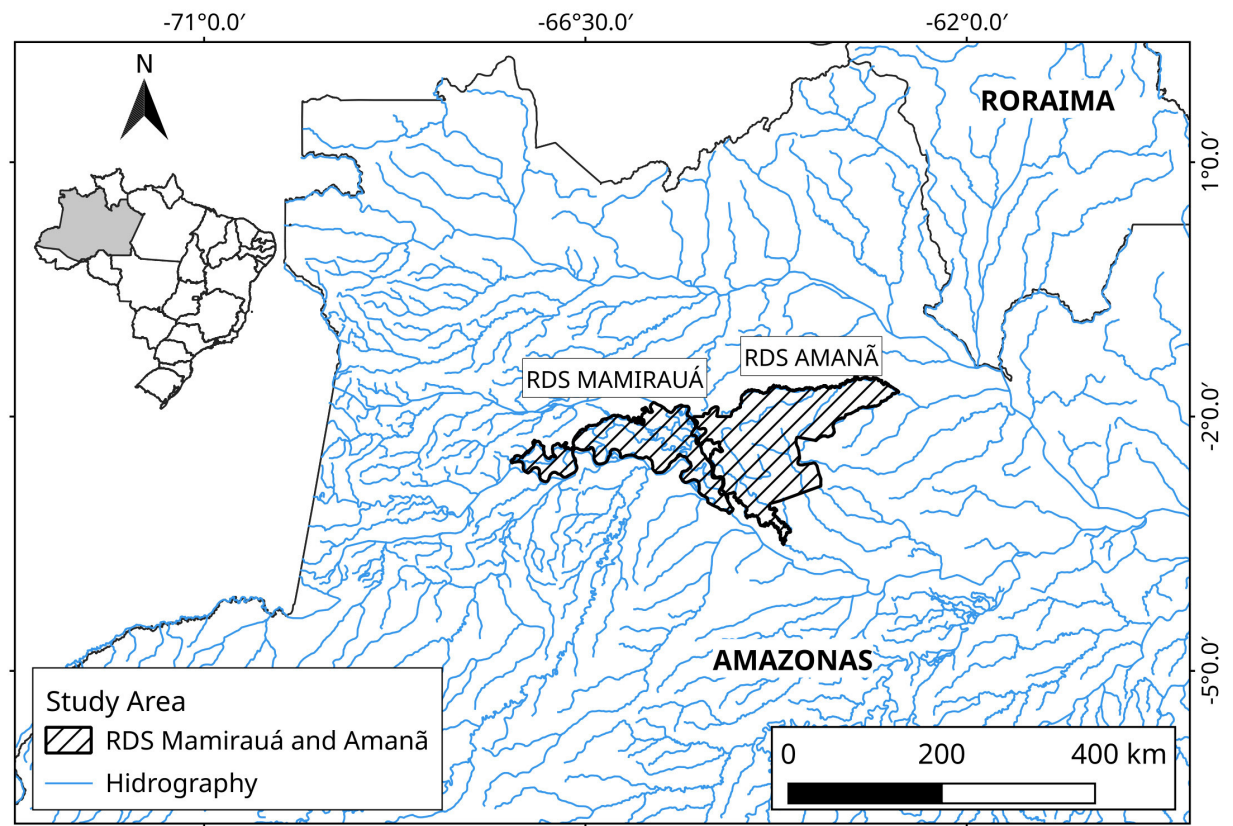

Figure 1. Map showing the location of the study areas: Sustainable Development Reserve (RDS in Portuguese) Mamirauá and Sustainable Development Reserve Amanã, in Amazonas state (highlighted in grey in the small map), Brazil. This figure is in color in the electronic version.

$\left.{ }^{\circ} \mathrm{C}\right)$ for 30 minutes and cooled at room temperature overnight. After these procedures, excess of $\mathrm{KMnO}_{4}$ was reduced by adding $1 \mathrm{~mL}$ of hydroxylamine hydrochloride $\left(\mathrm{NH}_{2} \mathrm{OH} . \mathrm{HCl}+12 \%\right.$ $\mathrm{NaCl}$ ). Finally, the extract was diluted to $12 \mathrm{~mL}$ with ultrapure water in falcon tubes.

The determination of $\mathrm{THg}$ was made by Cold Vapor Atomic Absorption Spectrometry (CVAAS, FIMS 400, Perkin Elmer) equipped with an autosampler (AS90) flow injection system (FIAS) using the Winlab software (Perkin Elmer) (Bastos et al. 1998).

Samples of certified material references from the National Research Council of Canada (DORM-3, fish protein, $n$ $=3$ ) and the Institute of Environmental Medicine of the Karolinska Institutet (human hair, $\mathrm{n}=8$ ), were used to test the method accuracy, reaching recovering rates of $96 \%$ and $97 \%$, respectively. All samples were analyzed in triplicate for an estimation of analytical variability and precision (coefficient of variation $<10 \%$ ).

As data were not normally distributed and sample sizes were small, we compared THg concentrations among species using the Kruskal-Wallis test, followed by pairwise comparisons using the Wilcoxon rank sum test. Leopardus wiedii was not included in the statistical analysis, as only one sample was available for this species. Differences between museum and free-living $P$. onca samples were tested with the Mann-Whitney-Wilcoxon test. Significance level was 5\% ( $\alpha$ $<0,05)$. Data analysis was carried out using the $\mathrm{R}$ statistical language, through the RStudio development environment.

\section{RESULTS}

THg concentrations ranged from 0.12 to $48.1 \mu \mathrm{g} \mathrm{g}^{-1}$ (Figure 2). Panthera onca samples from museum and live individuals did not differ significantly $(\mathrm{W}=24, \mathrm{p}=0.90)($ Table 1$)$, therefore the samples were pooled for subsequent analyses. $\mathrm{THg}$ concentrations differed significantly among species (KW $=7.00 ; \mathrm{p}=0.03)$, and the pairwise comparisons indicated that $P$. onca and $L$. pardalis had significantly higher concentrations then $P$. concolor $(\mathrm{p}=0.01)$. The single sample from $L$. wiedii had THg of $0.53 \mu \mathrm{g} \mathrm{g}^{-1}$ (Table 1). Gender of the greatest part of

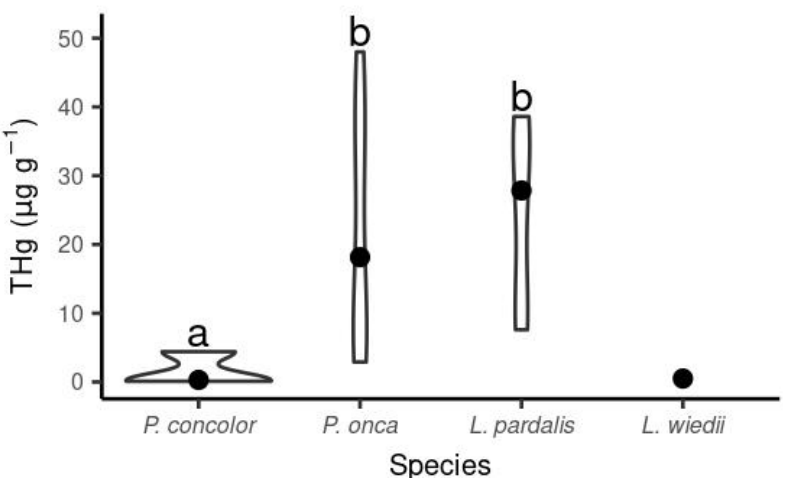

Figure 2. Violin plot of total mercury concentration $(\mathrm{THg})$ grouped by four felid species: Puma concolor $(n=3)$, Panthera onca $(n=14)$, Leopardus pardalis $(n=8)$ and Leopardus wiedii $(n=1)$. Values are the minimum and maximum measured; the width represents data aggregation; the black dot is the median. Species that differed significantly from each other are indicated by different letters $(P<0.05)$. Leopardus wiedii was not included in the comparative analysis, as there is only one sample. 
Table 1. Total $\mathrm{Hg}$ concentration in fur of wild neotropical felid species. $\mathrm{N}=$ number of individuals; $\mathrm{Hg}$ values are the mean $\pm \mathrm{SD}$ (range). Newman's values reported here are monomethyl mercury concentrations because THg reported in the paper are probably contaminated with inorganic Hg (more details in the discussion).

\begin{tabular}{lcccc}
\hline Species & $N$ & Origin & $\begin{array}{c}\text { Hg concentration } \\
\left(\mu \mathrm{g} \mathrm{g}^{-1}\right)\end{array}$ & Reference \\
\hline Leopardus pardalis & 3 & Texas & $0.70 \pm 0.56$ & Mora et al. 2000 \\
Puma concolor coryi $^{1}$ & 16 & Florida, USA & $0.60 \pm 0.38(0.03-1.52)$ & Newman et al. 2004 \\
Puma concolor coryi $^{2}$ & 26 & Florida, USA & $1.62 \pm 1.87(0.11-6.68)$ & Newman et al. 2004 \\
Puma concolor $^{3}$ & 3 & & $1.64 \pm 2.43(0.12-4.40)$ & this study \\
Panthera onca $^{3}$ & 9 & Brazilian Amazon, Mamirauá & $22.4 \pm 18.8(3.93-48.1)$ & this study \\
Panthera onca $^{4}$ & 5 & and Amanã RDS & $21.2 \pm 15.4(3.00-38.3)$ & this study \\
Leopardus pardalis $^{3}$ & 8 & & $24.5 \pm 13.5(7.65-38.6)$ & this study \\
Leopardus wiedii $^{3}$ & 1 & & 0.53 & this study \\
\hline
\end{tabular}

1- museum collection (tanned); 2 - museum collection (untanned); 3 - museum collection; 4 - living individuals

the individuals was not identified, but the only male identified had the highest detected concentration $\left(\right.$ P. onca, $\left.48.1 \mu \mathrm{g} \mathrm{g}{ }^{-1}\right)$, while the $P$. onca females $(\mathrm{n}=6)$ had a mean concentration of $17.9(3.0-38.7) \mu \mathrm{g} \mathrm{g}^{-1}$. Two L. pardalis individuals were identified as females, with $\mathrm{THg}$ concentrations of 10.6 and $24.6 \mu \mathrm{g} \mathrm{g}^{-1}$.

\section{DISCUSSION}

Several abiotic and biotic factors can affect $\mathrm{Hg}$ accumulation in wild mammals. The intra- and interspecific variation observed may be related to diet, age, home range, metabolism, gender and even seasonality (Newman et al. 2004; Eisler 2006).

Since diet is an important $\mathrm{Hg}$ source to biota, understanding food webs is crucial to analyze $\mathrm{Hg}$ accumulation. A review on metal accumulation in mammal species established that carnivores inserted in aquatic food webs usually have higher Hg levels compared to terrestrial food webs (Wren 1986). This is probably due to that an expressive part of the $\mathrm{Hg}$ methylation occurs in aquatic environments, especially in the sediment-water interface, macrophyte roots and hypolimnion of floodplain lakes (Guimarães et al. 2000; Correia et al. 2012; Brito et al. 2017). In these environments, there are methanogens and iron- and sulfate-reducing bacteria in their anoxic conditions (Kerin et al. 2006; Correia et al. 2012; Gilmour et al. 2013).

The species $P$. onca and $L$. pardalis presented the highest $\mathrm{Hg}$ concentrations. The main diet components of $P$. onca are caimans (Caiman crocodilus Linnaeus, 1758 and Melanosuchus niger Spix, 1825), which are associated with várzea-lake environments (Ramalho and Magnusson 2008; Rabelo et al. 2019). There is no study concerning dietary habits of $L$. pardalis in the study areas. In other areas, L. pardalis was reported as a generalist predator with opportunistic foraging strategy (Emmons 1987; Abreu et al. 2008), intensively using all types of habitat, such as forest, river and lake edges (Emmons 1987). In Araucaria pine forest in Paraná state (southern Brazil), L. pardalis fed on mammals, birds and squamates (Abreu et al. 2008). In a tropical rainforest in Peru, L. pardalis was reported to attack large birds and a rat (Emmons 1987). The prey biomass of $L$. pardalis, based on scats was mainly composed of mammalian prey $(48 \%)$ and fish, bird and reptile prey items (52\%) (Emmons 1987). Therefore, L. pardalis diet in our study area probably includes terrestrial items (e.g. terrestrial rodents) and animals associated with aquatic systems (e.g. reptiles, birds and fish). It is worth mentioning that non-aquatic species (e.g. birds) that have a diet associated with this environment will express the $\mathrm{Hg}$ contamination of the aquatic ecosystem (Cristol et al. 2008). Piscivorous birds, such as the great egret (Ardea alba Linnaeus, 1758), the Neotropical cormorant (Nannopterum brasilianus Gmelin, 1789) and the large-billed tern (Phaetusa simplex Gmelin, 1789), are abundant in the study areas (Cintra et al. 2007) and are likely part of the diet of L. pardalis. This opportunistic and wide range of food items may have been reflected in the wide range of $\mathrm{Hg}$ values observed for this species.

The species with the lowest $\mathrm{Hg}$ concentrations have diets based more on terrestrial prey. While the diet of $L$. wiedii consists mostly of small vertebrates (Rocha-Mendes et al. 2010; Bianchi et al. 2011), P. concolor prefers small and medium-sized mammals (Crawshaw and Quigley 2002). Although no dietary information exists for $P$. concolor and $L$. wiedii in the study areas, we can assume that $L$. wiedii, being a highly skilled arboreal felid, may feed mainly on arboreal small vertebrates. In the same way, despite individuals of P. concolor have skills to cross water bodies (Elbroch et al. 2010), the species is not as strongly associated with aquatic environments as P. onca (Figel et al. 2019).

The Amazon region is composed of a mosaic of distinct riverine basins with unique geomorphological and biogeochemical properties (Sioli 1956; Stallard 1985), along with a long ongoing history of gold mining, which can increase $\mathrm{Hg}$ concentrations above natural background levels at some basins (Silva-Forsberg et al. 1999). Thus, it is not possible to use $\mathrm{Hg}$ concentration information from one basin to assess $\mathrm{Hg}$ contamination in another basin. We did not find information about $\mathrm{Hg}$ concentrations in potential prey species of felids inhabiting our study area in the literature, so that comparisons 
of our data within the regional food web are impossible at this moment. This lack of information reinforces the importance of these first $\mathrm{Hg}$ results and the need to determine $\mathrm{Hg}$ levels in species from other trophic levels.

Data on differences in $\mathrm{Hg}$ accumulation between genders are conflicting for mammals. Higher concentrations were found in males of minks and otters (Beck 1977 apud Wren 1986), but in untanned Florida panthers (Table 1) there was no statistically significant difference in methylmercury fur content between genders (Newman et al. 2004). Considering that only a few individuals could have their gender identified in our sample (eight females and one male), no statistical analysis was possible.

In Brazil, there are few studies about $\mathrm{Hg}$ contamination in fur of wild mammals. Hair of giant otters (Pteronura brasiliensis Zimmermann, 1780) from Pantanal rivers contained 2.94 to $3.68 \mu \mathrm{g} \mathrm{g}^{-1}$ of $\mathrm{THg}$ (Fonseca et al. 2005). There are few studies worldwide on wild felids, yet none in the Amazon region (Table 1). THg concentrations in the fur of $L$. pardalis from the lower Rio Grande Valley, in Texas (USA) (Mora et al. (2000) were lower than in our study. A wide variation in monomethyl and inorganic mercury concentration was found in furs of $P$. concolor coryi (Newman et al. 2004), reaching values four times higher than our results when considering total $\mathrm{Hg}$ maximum values. Many of Newman's et al. (2004) samples were contaminated with inorganic $\mathrm{Hg}$, probably due to the museum storage and conservation processes of the $P$. concolor coryi furs, yet the monomethyl $\mathrm{Hg}$ concentration, according to the authors, is not susceptible to exogenous contamination, and represents approximately $80 \%$ of $\mathrm{THg}$ internal fur concentration. Their values for monomethyl $\mathrm{Hg}$ concentration ranged from 0.03 to $6.68 \mu \mathrm{g} \mathrm{g}^{-1}$, which falls within the same range as our values for $\mathrm{THg}$ for the same species. This could imply that our values for monomethyl $\mathrm{Hg}$ (not measured) would likely be lower than the concentrations for $P$. concolor coryi.

Newman et al. (2004) also discussed the effect of exogenous contamination on the assessment of $\mathrm{Hg}$ contamination in museum specimens, as mercuric chloride was used in the past for pest control, which could have led to contamination of some specimens. Upon request, the museums where their specimens were housed informed that their tanning processes involved the use of nonmercuric alum salts and tannic acids, among other compounds. Therefore, it is likely that the exogenous $\mathrm{Hg}$ contamination of the specimens originated from pest control products. In our study, the museum specimens were tanned by an artisanal process without the use of chemicals. We do not have information about pest control measures in the museum were our samples were stored. Nonetheless, there was no significant difference between our samples from museum skins and live individuals, which indicates that the skins were not contaminated by exogenous $\mathrm{Hg}$.

The identification of safe $\mathrm{Hg}$ levels for biota is challenging due to metabolic differences among species and the lack of studies on wild species. Analysis on visons, raccoons and otters suggested a range of normal concentrations in fur from 1 to $5 \mathrm{\mu g} \mathrm{g}^{-1}$ (Sheffy and Amant 1982). In a review, Eisler (2006) recommended that values higher than $2 \mu \mathrm{g} \mathrm{g}^{-1}$ in fur should be interpreted with caution, while Roelke et al. (1991) set a conservative "at risk" threshold for total mercury concentrations above $12.6 \mu \mathrm{g} \mathrm{g}^{-1}$ in the fur of Florida panthers (P. concolor couguar). In our study, $89 \%$ of the samples had $\mathrm{THg}$ values exceeding Eisler's (2006) proposed threshold of $2 \mu \mathrm{g} \mathrm{g}^{-1}$, and as much as 50\% exceeded the Roelke et al. (1991) threshold, which might point to harmful contamination levels. However, it is not possible to confirm any negative consequences based on the detected $\mathrm{Hg}$ concentrations and more data are necessary in order to understand the relevance of these concentrations for felids in the central Amazon várzea regions.

\section{CONCLUSIONS}

Our data suggest that the wild felid species in the central Brazilian Amazon floodplain regions of RDS Mamirauá and RDS Amanã, can be exposed to different mercury sources. We detected high concentrations of total mercury, as expected for a top predator, and interspecific differences that may be related to differences in dietary habits. Our limited sample size precluded further analyses to understand the high intraspecific variations found. The concentrations in some specimens exceeded $\mathrm{Hg}$ toxicity thresholds for mammals. The high THg concentrations detected in felid species highlight the importance of assessing mercury contamination in the Amazon region, including non-impacted conservation areas.

\section{ACKNOWLEDGMENTS}

This study is a result of the collaboration between the Biophysics Institute Carlos Chagas Filho at Universidade Federal do Rio de Janeiro and Instituto de Desenvolvimento Sustentável Mamirauá (IDSM). Special thanks to the IDSM staff for all the support and sample collection.

\section{REFERENCES}

Abreu, K.C.; Moro-Rios, R.F.; Silva-Pereira, J.E.; Miranda, J.M.D.; Jablonski, E.F.; Passos, F.C. 2008. Feeding habits of ocelot (Leopardus pardalis) in Southern Brazil. Mammalian Biology, 73: 407-411.

Ayres, J.M. 1995. As matas de várzea do Mamirauá: Médio Solimoes. 1st ed. Sociedade Civil Mamirauá, CNPq, Brasilia, 123 p.

Bastos, W.R.; Malm, O.; Pfeiffer, Wolfgang Christian; Clearly, D. 1998. Establishment and analytical quality control of laboratories for $\mathrm{Hg}$ determination in biological and geological samples in the Amazon, Brazil. Ciência e Cultura, 50: 255-260. 
Beck, D.L. 1977. Pesticide and heavy metal residues in Louisiana river otter. MSc thesis, Texas A\&M University, College Station, Texas.

Bianchi, R. de C.; Rosa, A.F.; Gatti, A.; Mendes, S.L. 2011. Diet of margay, Leopardus wiedii, and jaguarundi, Puma yagouaroundi, (Carnivora: Felidae) in Atlantic Rainforest, Brazil. Zoologia, 28: $127-132$.

Bonotto, D.M.; Wijesiri, B.; Vergotti, M.; da Silveira, E.G.; Goonetilleke, A. 2018. Assessing mercury pollution in Amazon River tributaries using a Bayesian Network approach. Ecotoxicology and Environmental Safety, 166: 354-358.

Borg, K.; Wanntorp, H.-E.; Erne, K.; Hanko, E. 1969. Alkyl mercury poisoning in terrestrial Swedish wildlife. Viltrevy, 6: 301-370.

Boudou, A.; Ribeyre, F. 1985. Experimental study of trophic contamination of Salmo gairdneri by two mercury compounds - $\mathrm{HgCl} 2$ and $\mathrm{CH} 3 \mathrm{HgCl}$ - analysis at the organism and organ levels. Water, Air, and Soil Pollution, 26: 137-148.

Brait, C.H.H.; Filho, N.R.A.; Furtado, M.M. 2009. Utilização de pelos de animais silvestres para monitoramento ambiental de Cd, Cr, Cu, Fe, Mn, Pb e Zn. Química Nova, 32: 1384-1388.

Brito, B.C.; Forsberg, B.R.; Kasper, D.; Amaral, J.H.F.; de Vasconcelos, M.R.R.; de Sousa, O.P.; et al. 2017. The influence of inundation and lake morphometry on the dynamics of mercury in the water and plankton in an Amazon floodplain lake. Hydrobiologia, 790: 35-48.

Burgess, N.M.; Evers, D.C.; Kaplan, J.D. 2005. Mercury and other contaminants in common loons breeding in Atlantic Canada. Ecotoxicology, 14: 241-252.

Burgess, N.M.; Meyer, M.W. 2008. Methylmercury exposure associated with reduced productivity in common loons. Ecotoxicology, 17: 83-91.

Burton, G.V.; Alley, R.J.; Rasmussen, G.L.; Orton, P.; Cox, V.; Jones, P.; et al. 1977. Mercury and behavior in wild mouse populations. Environmental Research, 14: 30-34.

Correia, R.R.S.; Miranda, M.R.; Guimarães, J.R.D. 2012. Mercury methylation and the microbial consortium in periphyton of tropical macrophytes: effect of different inhibitors. Environmental Research, 112: 86-91.

Crawshaw, P.G.; Quigley, H.B. 2002. Jaguar and puma feeding habits in the Pantanal, Brazil, with implications for their management and conservation. In: Medellin, R.A.; Equihua, C.; Chetkiewicz, C.L.B.; Crawshaw Jr., P.G.; Rabinowitz, A.; Redford, K.H.; Robinson, J.G.; Sanderson, E.W.; Taber, A. (Ed.). El Jaguar en el nuevo milenio. Una evaluacion de su estado, deteccion de prioridades y recomendaciones para la conservacion de los jaguares en America. Universidad Nacional Autonoma de Mexico/Wildlife Conservation Society, Mexico, D.F, p.223-235.

Cristol, D.A.; Brasso, R.L.; Condon, A.M.; Fovargue, R.E.; Friedman, S.L.; Hallinger, K.K.; Monroe A.P.; White, A.E. 2008. The movement of aquatic mercury through terrestrial food webs. Science, 320: 335-335.

Cintra, R.; Dos Santos, P.M.R.S.; Leite, C.B. 2007. Composition and structure of the lacustrine bird communities of seasonally flooded wetlands of western Brazilian Amazonia at high water. Waterbirds, 30: 521-540.
Cumbie, P.M. 1975. Mercury in hair of bobcats and raccoons. The Journal of Wildlife Management, 39: 419-425.

Dietz, R.; Riget, F.; Born, E.W.; Sonne, C.; Grandjean, P.; Kirkegaard, M.; et al. 2006. Trends in mercury in hair of Greenlandic polar bears (Ursus maritimus) during 1892-2001. Environmental Science \& Technology, 40: 1120-1125.

Duffy, L.K.; Duffy, R.S.; Finstad, G.; Gerlach, C. 2005. A note on mercury levels in the hair of Alaskan reindeer. Science of the Total Environment, 339: 273-276.

Eisler, R. 2006. Mercury Hazards to Living Organisms. CRC Press, Nova Iorque, 333p.

Elbroch, L.M.; Saucedo, C.; Wittmer, H.U. 2010. Swimming by pumas (Puma concolor) in Patagonia: rethinking barriers to puma movement. Studies on Neotropical Fauna and Environment, 45: 187-190.

Emmons, L.H. 1987. Comparative feeding ecology of felids in a neotropical rainforest. Behavioral Ecology and Sociobiology, 20: 271-283.

Evers, D. 2018. The effects of methylmercury on wildlife: a comprehensive review and approach for interpretation. In: Dellasala, D.A.; Goldstein, M.I. (Ed.). The Encyclopedia of the Anthropocene, v.1. Elsevier, 5: 181-194.

Farella, N.; Lucotte, M.; Davidson, R.; Daigle, S. 2006. Mercury release from deforested soils triggered by base cation enrichment. Science of the Total Environment, 368: 19-29.

Figel, J.J.; Botero-Cañola, S.; Forero-Medina, G.; Sánchez-Londoño, J.D.; Valenzuela, L.; Noss, R.F. 2019. Wetlands are keystone habitats for jaguars in an intercontinental biodiversity hotspot. PLOS ONE, 14: e0221705.

Fonseca, F.R.; Malm, O.; Francine Waldemarin, H. 2005. Mercury levels in tissues of Giant otters (Pteronura brasiliensis) from the Rio Negro, Pantanal, Brazil. Environmental Research, 98: 368-371.

Gilmour, C.C.; Podar, M.; Bullock, A.L.; Graham, A.M.; Brown, S.D.; Somenahally, A.C.; et al. 2013. Mercury methylation by novel microorganisms from new environments. Environmental Science \& Technology, 47: 11810-11820.

Guimarães, J.R.D.; Roulet, M.; Lucotte, M.; Mergler, D. 2000. Mercury methylation along a lake-forest transect in the Tapajós river floodplain, Brazilian Amazon: seasonal and vertical variations. Science of the Total Environment, 261: 91-98.

Hoffman, D.J.; Rattner, B.A.; Burton Jr, G.A.; Cairns, Jr, J. 2003. Handbook of Ecotoxicology. v.2. CRC Press, New York, 1316p.

Jernelöv, A.; Lann, H. 1971. Mercury accumulation in food chains. Oikos, 22: 403-406.

Kasper, D.; Forsberg, B.R.; do Amaral Kehrig, H.; Amaral, J.H.F.; Bastos, W.R.; Malm, O. 2018. Mercury in black waters of the Amazon. In: Myster, R.W. (Ed.). Igapó (Black-Water Flooded Forests) of the Amazon Basin, Springer International Publishing, Cham, p.39-56.

Kerin, E.J.; Gilmour, C.C.; Roden, E.; Suzuki, M.T.; Coates, J.D.; Mason, R.P. 2006. Mercury methylation by dissimilatory ironreducing bacteria. Applied and Environmental Microbiology, 72: 7919-7921.

Krey, A.; Ostertag, S.K.; Chan, H.M. 2015. Assessment of neurotoxic effects of mercury in beluga whales (Delphinapterus leucas), 
ringed seals (Pusa hispida), and polar bears (Ursus maritimus) from the Canadian Arctic. Science of the Total Environment, 509-510: 237-247.

Lacerda, L.D.; Pfeiffer, W.C. 1992. Mercury from gold mining in the Amazon environment: an overview. Quimica Nova, 15: 155-160.

Lechler, P.J.; Miller, J.R.; Lacerda, L.D.; Vinson, D.; Bonzongo, J.C.; Lyons, W.B.; et al. 2000. Elevated mercury concentrations in soils, sediments, water, and fish of the Madeira River basin, Brazilian Amazon: a function of natural enrichments? Science of the Total Environment, 260: 87-96.

Macdonald, D.W.; Loveridge, A.J. 2010. Biology and conservation of wild felids. Oxford Biology. Oxford University Press, New York, 762p.

Mora, M.A.; Laack, L.L.; Clare Lee, M.; Sericano, J.; Presley, R.; Gardinali, P.R.; et al. 2000. Environmental contaminants in blood, hair, and tissues of ocelots from the lower Rio Grande Valley, Texas, 1986-1997. Environmental Monitoring and Assessment, 64: 477-492.

Newman, J.; Zillioux, E.; Rich, E.; Liang, L.; Newman, C. 2004. Historical and other patterns of monomethyl and inorganic mercury in the Florida panther (Puma concolor coryi). Archives of Environmental Contamination and Toxicology, 48: 75-80.

Rabelo, R.M.; Aragón, S.; Bicca-Marques, J.C. 2019. Prey abundance drives habitat occupancy by jaguars in Amazonian floodplain river islands. Acta Oecologica, 97: 28-33.

Ramalho, E.E.; Magnusson, W.E. 2008. Uso do habitat por onçapintada (Panthera onca) no entorno de lagos de várzea, Reserva de Desenvolvimento Sustentável Mamirauá, AM, Brasil. Uakari, 4: 33-39.

Ramalho, E.E.; Macedo, J.; Vieira, T.M.; Valsecchi, J.; J, C.; Marmontel, M.; et al. 2009. Ciclo hidrológico nos ambientes de várzea da reserva de desenvolvimento sustentável mamirauá médio rio solimões, período de 1990 a 2008. Uakari, 5: 61-87.

Rashed, M.N.; Soltan, M.E. 2005. Animal hair as biological indicator for heavy metal pollution in urban and rural areas. Environmental Monitoring and Assessment, 110: 41-53.

Rice, K.M.; Walker, E.M.; Wu, M.; Gillette, C.; Blough, E.R. 2014. Environmental mercury and its toxic effects. Journal of Preventive Medicine \& Public Health, 47: 74-83.

Rocha-Mendes, F.; Mikich, S.B.; Quadros, J.; Pedro, W.A. 2010. Feeding ecology of carnivores (Mammalia, Carnivora) in Atlantic Forest remnants, Southern Brazil. Biota Neotropica, 10: 21-30.

Roelke, M.E.; Schultz, D.P.; Facemire, C.F.; Sundlof, S.F.; Royals, H.E. 1991. Mercury contamination in Florida panthers. Draft report prepared by the Technical Subcommittee of the Florida Panther Interagency Committee, USA. 69p. (https://catalog. data.gov/dataset/mercury-contamination-in-florida-panthersdraft/resource/a418c416-3f16-4eff-9e40-91093fbe0dd8). Accessed on 20 Aug 2019.

Roulet, M.; Lucotte, M.; Farella, N.; Serique, G. et al. 1998. Effects of recent human colonization on the presence of mercury in Amazonian ecosystems. Water, Air, and Soil Pollution, 112: 297-313

Scheuhammer, A.M.; Meyer, M.W.; Sandheinrich, M.B.; Murray, M.W. 2007. Effects of environmental methylmercury on the health of wild birds, mammals, and fish. Ambio, 36: 12-19.

Sheffy, T.B.; Amant, J.R.St. 1982. Mercury burdens in furbearers in Wisconsin. The Journal of Wildlife Management, 46: 1117-1120.

Silva-Forsberg, M.C.; Forsberg, B.R.; Zeidemann, V.K. 1999. Mercury contamination in humans linked to river chemistry in the Amazon Basin. Ambio, 28: 519-521.

Silveira, R.D.; Ramalho, E.E.; Thorbjarnarson, J.B.; Magnusson, W.E. 2010. Depredation by jaguars on caimans and importance of reptiles in the diet of jaguars. Journal of Herpetology, 44: 418-424.

Sioli, H. 1956. Über Natur und Mensch im brasilianischen Amazonasgebiet. Erdkunde, 10: 89-109.

Stallard, R.F. 1985. River chemistry, geology, geomorphology, and soils in the Amazon and Orinoco Basins. In: Drever, J.I. (Ed.). The Chemistry of Weathering, Springer Netherlands, Dodrecht, p.293-316.

Ullrich, S.M.; Tanton, T.W.; Abdrashitova, S.A. 2001. Mercury in the aquatic environment: a review of factors affecting methylation. Critical Reviews in Environmental Science and Technology, 31: 241-293.

Wiener, J.G.; Krabbenhoft, D.P.; Heinz, G.H.; Scheuhammer, A.M. 2003. Ecotoxicology of mercury. In: Hoffman, D.J.; Rattner, B.A.; Burton Jr, G.A.; Cairns, Jr, J. (Ed.). Handbook of Ecotoxicology. v.2. CRC Press, New York, p.409-463.

Wolfe, M.F.; Schwarzbach, S.; Sulaiman, R.A. 1998. Effects of mercury on wildlife: a comprehensive review. Environmental Toxicology and Chemistry, 17: 146-160.

WHO. 1990. IPCS Environmental Health Criteria 101: Methylmercury. International Programme of Chemical Safety. World Health Organization, Geneva, Switzerland.

Wren, C.D. 1986. A review of metal accumulation and toxicity in wild mammals. Environmental Research, 40: 210-244.

RECEIVED: 03/09/2019

ACCEPTED: 07/01/2020

ASSOCIATE EDITOR: Carlos José S. Passos 
SUPPLEMENTARY MATERIAL (only available in the electronic version)

LOPES et al. Total mercury in wild felids occurring in protected areas in the central Brazilian Amazon

Table S1. Mercury concentrations ( $\mu \mathrm{g} \mathrm{g} \mathrm{g}^{-1}$, dry weight) in wild felid fur of Leopardus pardalis, Panthera onca, Puma concolor and Leopardus wiedii from Mamirauá and Amanã sustainable development reserves (Amazonas, Brazil). NA = data not available.

\begin{tabular}{|c|c|c|c|c|c|}
\hline Species & Location & Date & Sex & Source & $\mathrm{Hg}(\mu \mathrm{g} g)$ \\
\hline Leopardus pardalis & Amanã & NA & NA & museum & 9.14 \\
\hline Leopardus pardalis & Amanã & $20 \mathrm{Jul} 2010$ & NA & museum & 38.1 \\
\hline Leopardus pardalis & Amanã & NA & NA & museum & 31.1 \\
\hline Leopardus pardalis & Amanã & $14 \operatorname{Jan} 2007$ & female & museum & 10.6 \\
\hline Leopardus pardalis & Amanã & 28 Mar 2008 & female & museum & 24.6 \\
\hline Leopardus pardalis & Amanã & $14 \operatorname{Jan} 2007$ & NA & museum & 36.1 \\
\hline Leopardus pardalis & Amanã & 10 Mar 2007 & NA & museum & 38.6 \\
\hline Leopardus pardalis & Amanã & 28 Feb 2008 & NA & museum & 7.65 \\
\hline Panthera onca & Mamirauá & 24 Sep 2009 & female & museum & 5.63 \\
\hline Panthera onca & Mamirauá & 11 May 2010 & NA & living & 35.1 \\
\hline Panthera onca & Mamirauá & 16 Nov 2010 & female & living & 19.8 \\
\hline Panthera onca & Mamirauá & 30 Nov 2010 & female & living & 3.00 \\
\hline Panthera onca & Mamirauá & 3 Jul 2011 & male & museum & 48.1 \\
\hline Panthera onca & Mamirauá & 1 Apr 2010 & NA & living & 38.3 \\
\hline Panthera onca (juvenile) & Mamirauá & 16 Nov 2010 & female & living & 10.1 \\
\hline Panthera onca & Amanã & 2011 & female & museum & 38.7 \\
\hline Panthera onca & Amanã & 1 May 2011 & female & museum & 30.4 \\
\hline Panthera onca & NA & NA & NA & museum & 47.1 \\
\hline Panthera onca & NA & NA & NA & museum & 16.5 \\
\hline Panthera onca & NA & NA & NA & museum & 5.87 \\
\hline Panthera onca & NA & NA & NA & museum & 5.26 \\
\hline Panthera onca & NA & NA & NA & museum & 3.93 \\
\hline Puma concolor & Amanã & NA & NA & museum & 4.40 \\
\hline Puma concolor & Amanã & NA & NA & museum & 0.39 \\
\hline Puma concolor & Amanã & NA & NA & museum & 0.12 \\
\hline Leopardus wiedii & Amanã & NA & NA & museum & 0.53 \\
\hline
\end{tabular}

